\title{
EDITORIAL
}

\section{QUANDO A PRÁTICA SE APROXIMA DA TEORIA...}

A maior parte do processo de desenvolvimento da enfermagem nos últimos 50 anos originou-se dos estudos teóricos que proporcionaram a nós, enfermeiras, um magnífico acervo de teorias, modelos teóricos e conceitualizaçōes, a respeito de o que é, a quem se destina, onde se realiza, para que serve a enfermagem, e com que instrumentos e conhecimentos se executam os cuidados de enfermagem.

O nível de abstração às vezes muito alto impedia que as enfermeiras se apropriassem deste saber para colocá-lo à disposiçāo dos que fazem o dia-a-dia da enfermagem, criando o que se chamou de dicotomia entre o saber e o fazer enfermagem, entre os que pesquisam e ensinam enfermagem, e os que praticam. Destes desencontros entre a teoria e a prática criaram-se pressupostos que confirmaram que na prática a teoria era outra e que dificilmente um caminho comum seria viabilizado.

Passados cinqüenta anos, encontramo-nos hoje no limiar do terceiro milênio, com um panorama definido pelas competências práticas das enfermeiras, logradas por sucessivas investidas nas teorias de enfermagem com um retorno imediato às origens do fazer, porém desta feita do fazer convalidado pelo saber.

$\mathrm{O}$ que queremos dizer é que cada vez mais, um maior número de enfermeiros e em diversos lugares do Brasil, busca trazer e levar, num ir e vir contínuo, da teoria à prática e da prática à teoria, os conceitos, os pressupostos, os princípios e os significados pertinentes à ciência da enfermagem. futuro.

Esta evoluçāo na busca do domínio da essência da enfermagem é o nosso

\section{Tamara Iwanow Cianciarullo}

